\title{
Accounting
}

\section{The effects of organization size and manager's educational background on responsibility accounting: Evidences from Vietnamese cement enterprises}

\author{
Trung Tuan Tran ${ }^{\text {**, The Hung Dinh }}{ }^{\mathrm{a}}$ and Huu Anh Nguyen ${ }^{\mathrm{a}}$
}

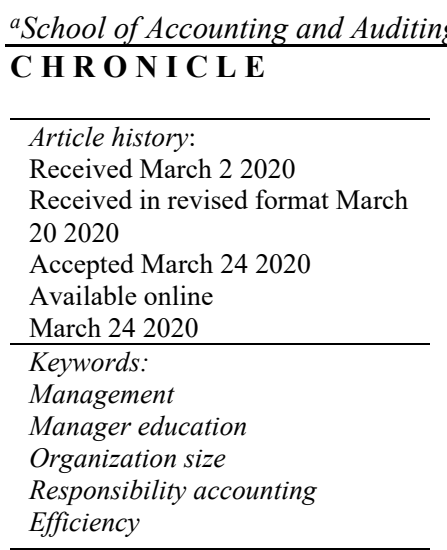

\begin{abstract}
A B S T R A C T
Responsibility accounting is important content of management accounting. This is an accounting system provides the flexible information, timely and accurately that to assess efficiency of managers and improve performance of firms. The paper aims to identify effects of organization size and level of manager education on responsibility accounting in Vietnamese cement enterprises. In this paper, SPSS 22 was used to collect and analysis data by distributing 103 questionnaires on managers and head of departments from Vietnamese cement manufacturers. The Results of research have shown that there are significant relationships between organization size, and level of manager education and responsibility accounting in the Vietnamese cement enterprises.
\end{abstract}

\section{Introduction}

During the past few years, Vietnam's economy has been connected with the regional and the rest of world and, as a result, competition has become intense. Therefore, in order to survive and develop, enterprises must continuously expand their business and production activities. As the scale of business production increases, enterprises must implement decentralization and decentralized management and managers must be responsible for the operations of their own division. This is the premise and motivation to form an accounting system, which is responsibility accounting (RA). This is an accounting system which provides some flexible information, timely and accurately and helps us assess managers' efficiency. However, responsibility accounting in general and factors that affect responsibility accounting are relatively new concept in Vietnam. This research investigates the effects of organization size and the level of managers' education on responsibility accounting in Vietnamese cement enterprises.

\section{Literature Review}

\subsection{Responsibility accounting}

According to Higgins (1952), responsibility accounting is the accounting system which is organized in enterprise to collect and report on expenses at the levels of management in enterprise. Each manager of organization shall be

\footnotetext{
* Corresponding author.

E-mail address: trungtuanktqd@gmail.com (T. T. Tran) 
responsible to control an allocated expense. Responsibility accounting (RA) is closely related to cost accounting. One of the important goals of responsibility accounting is to control the cost at the basic levels of supervisor (Kellogg, 1962). Responsibility accounting is the accounting system which collects, summarizes and reports on accounting according to personal responsibility of manager (Hermanson, Edwards, \& Salmonson, 1987). Responsibility accounting is the system spreading decision-making authority and allocation of resources meanwhile maintaining concentrated information and control through the evaluation of performance and accountability (Bloomfield, Coombs, Cooper, \& Rea, 1992). RA is the accounting system acknowledged through different responsibility centers in the entire organization and reflects results, performance of each center by revenue and cost items (Horngren, Foster, \& Datar, 2000). According to Atkinson et al. (2001), responsibility accounting is the accounting system which includes collection, summarization and report on accounting information related to costs, income and operating data by each scope of responsibility or unit in organization. Responsibility accounting is the management method in order for design of accounting system to obtain control efficiency through the direct relationship between accounting report and the head in the organizational structure of company at all management levels (Meda, 2003). Responsibility accounting connects the personal performance report with the heads of the different management levels to determine the level of obtaining goal of management levels, and responsibility centers (Rajbi, 2004). Responsibility accounting is the control system of manager based on principles of authorization and determination of responsibility of manager. Such system includes managers who make business decisions in separate fields and responsible for activities in responsibility centers (Reddy, 2008). Responsibility accounting is the management control system based on principles of decentralization and determination of the position of responsibility. Manager shall be entitled to make decision and be responsible for activities in a specific field and responsibility center managed by them. Another basic task of responsibility accounting is the measurement of performance of managers. (Okoye \& Ngozi, 2009). Responsibility accounting is the cost control method determined by managers of enterprises (Fowzia, 2011). Responsibility accounting shall provide managers with information to control operating process and evaluate performance of subordinate managers (E., 2012).

\subsection{Elements of responsibility accounting}

Considering the perspective and approach of the organizational structure and the level of decentralization, the liability of accounting is divided into the responsibility centers. Based on the organizational structure and degree of decentralization, enterprise system centers are associated with responsibilities. Currently, most researchers believe that there are 4 types of responsibility center; namely cost center, the revenue center, profit center and investment center (Garrison \& Noreen, 2008; Kinney \& Raiborn, 2011).

Considering the views and approaches of content, responsibility accounting has the following elements: (Hansen \& Mowen, 2005), Responsibility Accounting includes four essential elements including Assigning the responsibilities, Building the standards and measurements on achievement, Evaluating the achievements and Distributing the prizes. From 4 basic elements as above, in their study, Gharayba et al. (2011) developed the four elements into 7 elements and others (e.g. Hanini, 2013) used accounting charge liability, responsibility accounting. RA shall divide the organizational structure of the enterprise to its various responsibility centers; Responsibility Accountants decentralize power to the administrator at the center of responsibility with clear authority and administrator shall be responsibility for the achievement of the central responsibility; Responsibility Accounting shall divide the costs and revenues to the central responsibility as possibilities and limits the power of the center. Also; Responsibility Accounting implementation link between the estimates with actual results at the center of responsibility. Accountants are responsible for encouraging all employees of each center to ensure appropriate cost estimates, feasibility and can achieve the overall goals of the business; Responsibility accounting estimates are used to control and measure the results through the comparison with the actual results of each responsibility center; Responsibility accounting prepares a report to analyze the difference between actual results and the estimates to determine who shall be responsibility for the difference; Responsibility accounting set up an incentive system which has a close relationship with the estimation results at the center of responsibility to limit undesirable disparities and promote good differences, and determine who is responsible for the difference in order to encourage employees to improve their achievement and the overall success of the entire enterprise (Gharayba et al., 2011; Hanini, 2013).

\subsubsection{Factors affected on responsibility accounting}

There is not a standard design and the best for management accounting system in general and responsibility accounting in particular but dependent on the factors in organization. Many authors have put forward a lot of factors affected on the accounting system in general and responsibility accounting in particular such as: Type of self-proclamation and behavior, size of business (revenue, total of asset, number of employee), position of administrator, human factor. Kellogg (1962) studied the development of RA and looked at the relationship between RA with organizational structure, cost accounting, cost estimation, cost control. Accountants are responsible for presenting and defining the concept of management accounting in a more comprehensive way. Accountants responsibility, organizational responsibility, cost accounting, operational budget controls are combined to meet management requirements. Accountants have close contact with cost accounting. One of the main goals of accountancy is to 
control costs at the grassroots level. Any proposal to allocate costs to lower levels should be provided by special analysis reports (Kellogg, 1962). Rowe et al. (2008) pointed out practical evidence of the design of accounting goals or redesign in general. In their view, accountability in particular depends on the level, goal and pace of organizational change. When there is a change in the level, purpose, speed of the organizational change process, the financial performance of the managers in the responsibility centers may change. The study also found that the use of accountancy to manage liability centers is an important method for achieving business goals (Rowe et al., 2008).

Belkaoui (1981) explored the relationship between self-disclosure and attitudes toward accountability, and explored the relationship between self-presentation and attitudes toward accountability. In this study, the author used a quantitative method with 55 questionnaires sent to Canadian government officials. The author developed a self-published set of observations and measured 32 variables. The results of factor analysis of self-presentation included five factors and self-expression directly related to attitudes and accountability (Belkaoui, 1981). Dowd (2001) explored the impact of products on accountability at power companies. The results show that the more heterogeneous the product and the more varied the use of production technologies is, the greater the level of collection and reporting costs, the more cost centers is (Dowd, 2001). Zahirul and Wendy (2000) used organization size factors to test the influence of these factors on responsibility accounting.

\section{Research Methodology}

\subsection{Research Model}

This study uses quantitative research method to determine the effects of organization size and level of managers' education on responsibility accounting in the Vietnamese cement enterprises. The model can be generalized as follows:

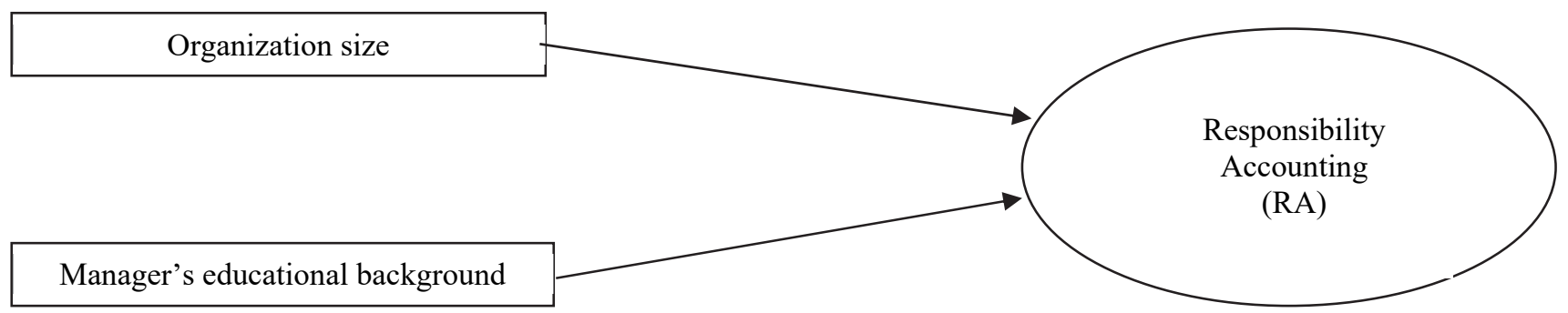

\subsection{Hypothesis}

Fig. 1. Proposed Research Model

Based on the Literature Review result given and scope of the research, there were 2 hypotheses used to assess the effects of organization size and level of manager's education on responsibility accounting in the Vietnamese cement enterprises:

$\mathrm{H}_{1}$ : There is a significant relationship between organization size and responsibility accounting in the Vietnamese cement enterprises.

$\mathrm{H}_{2}$ : There is a significant relationship between managers' educational background and responsibility accounting in the Vietnamese cement enterprises.

The research designs some questionnaires and collect the necessary data by means of surveys with different levels and sends them to managers in the Vietnamese cement enterprises; thereby synthesizing and analyzing data using the SPSS 22 statistical software to evaluate effects of organization size and level of manager education on responsibility accounting in Vietnamese cement enterprises. Research on using the measurement scale included 43 variables on measuring the level of responsibility accounting application of Hanini (2013) which was also developed by author. In order to make sure that 43 variables of the survey and new variables is reliable, Cronbach Alpha verification on verifying the scale of measurement is used. In this study, the author uses organization size by Zahirul and Wendy (2000) and the level of managers' educational background to test the effects of these factors on responsibility accounting. Organization size includes: Total average asset, average revenue and average number of workers in Vietnamese Cement enterprises. Until 2019 Vietnam has 74 cement enterprises. Responsibility centers are headed by the administrators in business and responsible for managing all the operations of the responsibility centers to reach the researching targets. Researches in the world about the responsibility accounting were implemented to gather the information from the business administrators, including Member of Management Board, Board of Directors, Chief/Deputy Chief of Departments/Sections, foremen of workshop (e.g. Al-Bawab, 2012; Hanini, 2013; Al-shomaly, 2013). This research applies quantitative research by utilizing 210 responses of questionnaire sent to managers of Vietnamese Cement enterprises managers 
through hard copy and google form. Research was accomplished by using the quantitative research methods based on previous researches on the responsibility accounting. The author conducts the surveys at Vietnamese cement enterprises. Depending on the characteristics and the ability to collect the answer sheets of each enterprises, the research has sent an average of 10 survey papers to each Vietnamese cement enterprises. Data collected from questionnaires have been analyzed by specialized SPSS data analysis software. The research will use the SPSS 22 software to support for descriptive statistics, frequency analysis and ANOVA analysis. There were 118 responses, accounting for $58 \%$.

\section{Results and Discussion}

The research used data from 210 copies of questionnaire sent to managers such as members of management board, directorate, heads of different departments, Vietnamese cement enterprises with 118 collected responses. After excluding invalid responses, the rest of 103 ones were utilized with SPSS to give the Cronbach's alpha given in Table 1.

\section{Table 1}

Cronbach's Alpha result

\begin{tabular}{ccc}
\hline Cronbach's Alpha & N of Items \\
\hline .957 & 46 & \\
\hline & (Source: author's data processing result)
\end{tabular}

Cronbach's Alpha analysis shows that Cronbach's Alpha $=0.957$, which means variables are reliable and the result of general variable in Table 2 proves indispensability of these variables. Table 3 demonstrates the results of principal component analysis with Verimax rotation. According to Table 3, there are seven components; namely Organizational structure divided, Authority divided, Distribute cost and revenues, Prepare estimates budget, Use estimates budget, Use reports and Incentives system.

Table 2

KMO and Bartlett's Test

Kaiser-Meyer-Olkin Measure of Sampling Adequacy,

Bartlett's Test of Sphericity Approx, Chi-Square

.859

Df

2141.499

Sig,

Table 3

Component rotation results

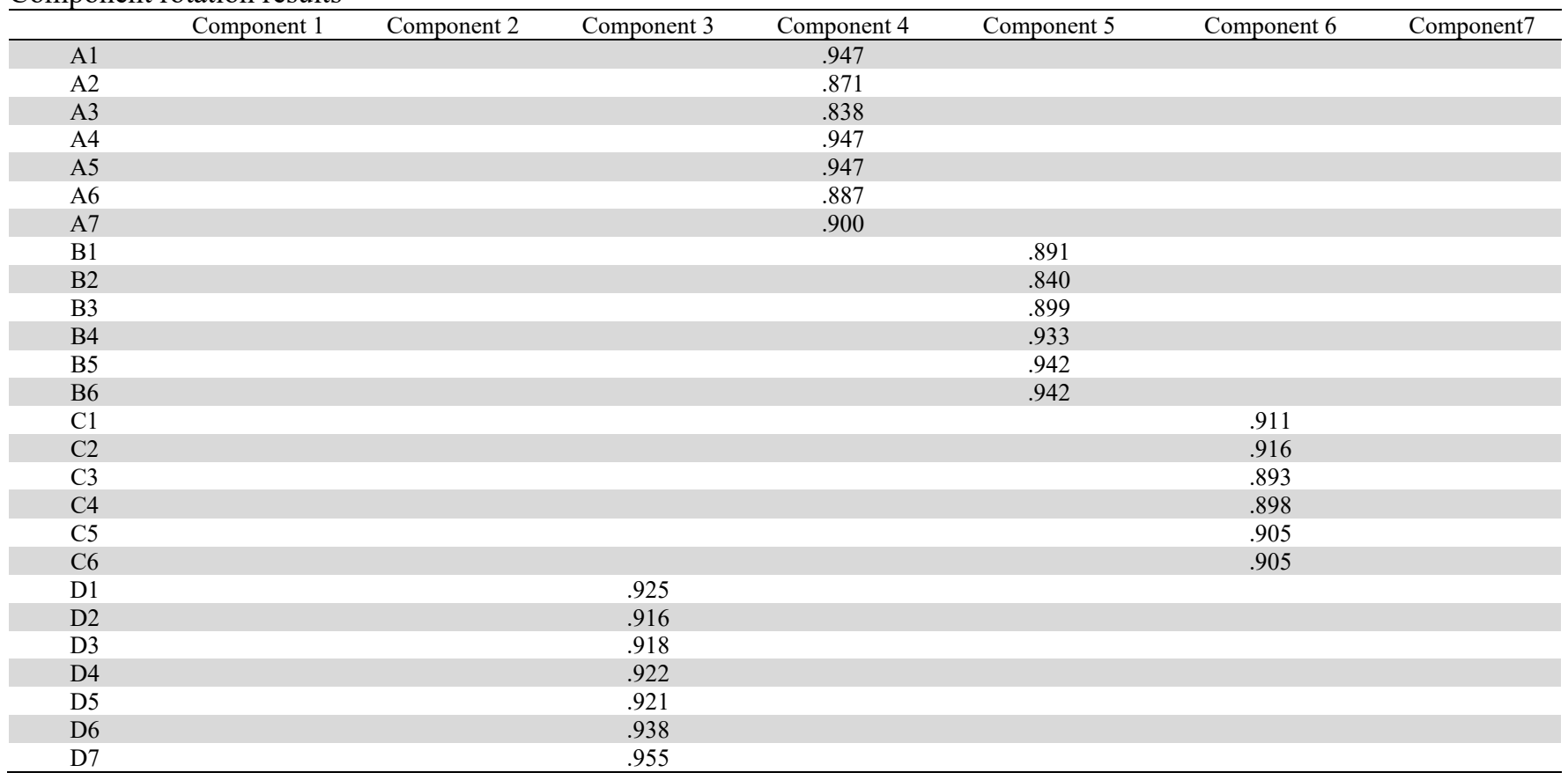


Table 3

Component rotation results (Continued)

\begin{tabular}{|c|c|c|c|c|c|c|c|}
\hline & Component 1 & Component 2 & Component 3 & Component 4 & Component 5 & Component 6 & Component7 \\
\hline E1 & & & & & & & .902 \\
\hline E2 & & & & & & & .902 \\
\hline E3 & & & & & & & .892 \\
\hline $\mathrm{E} 4$ & & & & & & & .867 \\
\hline E5 & & & & & & & .835 \\
\hline $\mathrm{F} 1$ & .952 & & & & & & \\
\hline $\mathrm{F} 2$ & .917 & & & & & & \\
\hline F3 & .915 & & & & & & \\
\hline $\mathrm{F} 4$ & .928 & & & & & & \\
\hline F5 & .950 & & & & & & \\
\hline F6 & .936 & & & & & & \\
\hline F7 & .915 & & & & & & \\
\hline F8 & .943 & & & & & & \\
\hline G1 & & .948 & & & & & \\
\hline $\mathrm{G} 2$ & & .935 & & & & & \\
\hline G3 & & .929 & & & & & \\
\hline G4 & & .937 & & & & & \\
\hline G5 & & .936 & & & & & \\
\hline G6 & & .939 & & & & & \\
\hline G7 & & .955 & & & & & \\
\hline
\end{tabular}

\subsection{Effects of the managers' educational background on responsibility accounting}

In order to study the effects of the managers' educational background on responsibility accounting, we have performed an ANOVA test. Table 4 shows the results of the survey and as we can observe, F-value yields meaningful results when the level of significance is one percent. Therefore, all components have meaningful relationships with responsibility accounting.

\section{Table 4}

Test ANOVA

\begin{tabular}{|c|c|c|c|c|c|c|}
\hline & & Sum of Squares & $\mathrm{df}$ & Mean Square & $\mathrm{F}$ & Sig. \\
\hline \multirow[t]{3}{*}{ Organizational structure divided } & Between Groups & 6.268 & 3 & 2.089 & 2.610 & .006 \\
\hline & Within Groups & 79.247 & 99 & .800 & & \\
\hline & Total & 85.515 & 102 & & & \\
\hline \multirow[t]{3}{*}{ Authority divided } & Between Groups & 12.557 & 3 & 4.186 & 3.827 & .012 \\
\hline & Within Groups & 108.278 & 99 & 1.094 & & \\
\hline & Total & 120.835 & 102 & & & \\
\hline \multirow[t]{3}{*}{ Distribute cost and revenues } & Between Groups & 2.395 & 3 & .798 & .668 & .004 \\
\hline & Within Groups & 118.323 & 99 & 1.195 & & \\
\hline & Total & 120.718 & 102 & & & \\
\hline \multirow[t]{3}{*}{ Prepare estimates budget } & Between Groups & 6.479 & 3 & 2.160 & 1.961 & .012 \\
\hline & Within Groups & 109.035 & 99 & 1.101 & & \\
\hline & Total & 115.515 & 102 & & & \\
\hline \multirow[t]{3}{*}{ Use estimates budget } & Between Groups & 7.631 & 3 & 2.544 & 3.145 & .029 \\
\hline & Within Groups & 80.078 & 99 & .809 & & \\
\hline & Total & 87.709 & 102 & & & \\
\hline \multirow[t]{3}{*}{ Use reports } & Between Groups & 9.704 & 3 & 3.235 & 4.152 & .008 \\
\hline & Within Groups & 77.131 & 99 & .779 & & \\
\hline & Total & 86.835 & 102 & & & \\
\hline \multirow[t]{3}{*}{ Incentives system } & Between Groups & 10.712 & 3 & 3.571 & 3.819 & .012 \\
\hline & Within Groups & 92.550 & 99 & .935 & & \\
\hline & Total & 103.262 & 102 & & & \\
\hline
\end{tabular}

\subsection{Effects of the average number of workers on responsibility accounting}

The study has sloe performed ANOVA test to examine the effect of the average number of workers on responsibility accounting. The results have indicated that there were some statistically significant relationship between seven components and the average number of workers. 
Table 5

Test ANOVA

\begin{tabular}{|c|c|c|c|c|c|c|}
\hline & & Sum of Squares & df & Mean Square & $\mathrm{F}$ & Sig. \\
\hline \multirow{3}{*}{$\begin{array}{l}\text { Organizational structure } \\
\text { divided }\end{array}$} & Between Groups & .129 & 1 & .129 & .152 & .007 \\
\hline & Within Groups & 85.386 & 101 & .845 & & \\
\hline & Total & 85.515 & 102 & & & \\
\hline \multirow[t]{3}{*}{ Authority divided } & Between Groups & .246 & 1 & .246 & .206 & .001 \\
\hline & Within Groups & 120.588 & 101 & 1.194 & & \\
\hline & Total & 120.835 & 102 & & & \\
\hline \multirow{3}{*}{$\begin{array}{l}\text { Distribute cost and } \\
\text { revenues }\end{array}$} & Between Groups & 1.296 & 1 & 1.296 & 1.096 & .012 \\
\hline & Within Groups & 119.422 & 101 & 1.182 & & \\
\hline & Total & 120.718 & 102 & & & \\
\hline \multirow{3}{*}{$\begin{array}{l}\text { Prepare estimates } \\
\text { budget }\end{array}$} & Between Groups & .024 & 1 & .024 & .021 & .006 \\
\hline & Within Groups & 115.491 & 101 & 1.143 & & \\
\hline & Total & 115.515 & 102 & & & \\
\hline \multirow[t]{3}{*}{ Use estimates budget } & Between Groups & 1.669 & 1 & 1.669 & 1.960 & .015 \\
\hline & Within Groups & 86.039 & 101 & .852 & & \\
\hline & Total & 87.709 & 102 & & & \\
\hline \multirow[t]{3}{*}{ Use reports } & Between Groups & 1.314 & 1 & 1.314 & 1.552 & .026 \\
\hline & Within Groups & 85.520 & 101 & .847 & & \\
\hline & Total & 86.835 & 102 & & & \\
\hline \multirow[t]{3}{*}{ Incentives system } & Between Groups & 1.408 & 1 & 1.408 & 1.396 & .024 \\
\hline & Within Groups & 101.855 & 101 & 1.008 & & \\
\hline & Total & 103.262 & 102 & & & \\
\hline
\end{tabular}

(Source: author's data processing result)

\subsection{Effects of average revenue on responsibility accounting}

Similarly, the effects of average revenue on responsibility accounting has been examined using ANOVA test and the results are summarized in Table 6 . The results have indicated that there were positive and meaningful relationship between two factors when the level of significance is five percent.

\section{Table 6}

Test ANOVA

\begin{tabular}{|c|c|c|c|c|c|c|}
\hline & & Sum of Squares & df & Mean Square & $\mathrm{F}$ & Sig. \\
\hline \multirow{3}{*}{$\begin{array}{l}\text { Organizational structure } \\
\text { divided }\end{array}$} & Between Groups & .846 & 3 & .282 & .330 & .004 \\
\hline & Within Groups & 84.669 & 99 & .855 & & \\
\hline & Total & 85.515 & 102 & & & \\
\hline \multirow[t]{3}{*}{ Authority divided } & Between Groups & 4.163 & 3 & 1.388 & 1.177 & .032 \\
\hline & Within Groups & 116.672 & 99 & 1.179 & & \\
\hline & Total & 120.835 & 102 & & & \\
\hline \multirow{3}{*}{$\begin{array}{l}\text { Distribute cost and } \\
\text { revenues }\end{array}$} & Between Groups & 2.449 & 3 & .816 & 683 & .045 \\
\hline & Within Groups & 118.269 & 99 & 1.195 & & \\
\hline & Total & 120.718 & 102 & & & \\
\hline \multirow[t]{3}{*}{ Prepare estimates budget } & Between Groups & 1.404 & 3 & .468 & .406 & .049 \\
\hline & Within Groups & 114.111 & 99 & 1.153 & & \\
\hline & Total & 115.515 & 102 & & & \\
\hline \multirow[t]{3}{*}{ Use estimates budget } & Between Groups & 1.750 & 3 & .583 & 672 & .016 \\
\hline & Within Groups & 85.959 & 99 & .868 & & \\
\hline & Total & 87.709 & 102 & & & \\
\hline \multirow[t]{3}{*}{ Use reports } & Between Groups & 9.971 & 3 & 3.324 & 4.281 & .007 \\
\hline & Within Groups & 76.864 & 99 & .776 & & \\
\hline & Total & 86.835 & 102 & & & \\
\hline \multirow[t]{3}{*}{ Incentives system } & Between Groups & 2.312 & 3 & .771 & .756 & .022 \\
\hline & Within Groups & 100.950 & 99 & 1.020 & & \\
\hline & Total & 103.262 & 102 & & & \\
\hline
\end{tabular}

(Source: author's data processing result)

\subsection{Effects of average asset on Responsibility accounting}

Finally, the study has considered the relationship between the average asset and responsibility accounting and Table 7 shows have confirmed that there were positive and meaningful relationship between two variables.

Thus, results of testing the data in Vietnamese Cement Enterprises show:

- The level of managers' educational background in Vietnamese Cement Enterprises impacts on the responsibility accounting, the higher education level of administrators, the higher ability to apply with the responsibility accounting in enterprises. 
- Size (total of average asset, average revenue, average number of workers) of Vietnamese Cement Enterprises have had impacts on responsibility accounting which means, the greater the enterprises in scale, the higher the ability to apply with the element of responsibility accounting.

Table 7

Test ANOVA

\begin{tabular}{|c|c|c|c|c|c|c|}
\hline & & Sum of Squares & df & Mean Square & $\mathrm{F}$ & Sig. \\
\hline \multirow{3}{*}{$\begin{array}{l}\text { Organizational structure } \\
\text { divided }\end{array}$} & Between Groups & 9.224 & 3 & 3.075 & 3.990 & .010 \\
\hline & Within Groups & 76.290 & 99 & .771 & & \\
\hline & Total & 85.515 & 102 & & & \\
\hline \multirow{3}{*}{ Authority divided } & Between Groups & 15.858 & 3 & 5.286 & 4.985 & .003 \\
\hline & Within Groups & 104.977 & 99 & 1.060 & & \\
\hline & Total & 120.835 & 102 & & & \\
\hline \multirow[t]{3}{*}{ Distribute cost and revenues } & Between Groups & 11.191 & 3 & 3.730 & 3.372 & .021 \\
\hline & Within Groups & 109.527 & 99 & 1.106 & & \\
\hline & Total & 120.718 & 102 & & & \\
\hline \multirow[t]{3}{*}{ Prepare estimates budget } & Between Groups & 6.087 & 3 & 2.029 & 1.836 & .046 \\
\hline & Within Groups & 109.427 & 99 & 1.105 & & \\
\hline & Total & 115.515 & 102 & & & \\
\hline \multirow[t]{3}{*}{ Use estimates budget } & Between Groups & 8.638 & 3 & 2.879 & 3.605 & .016 \\
\hline & Within Groups & 79.071 & 99 & .799 & & \\
\hline & Total & 87.709 & 102 & & & \\
\hline \multirow[t]{3}{*}{ Use reports } & Between Groups & 19.272 & 3 & 6.424 & 9.413 & .000 \\
\hline & Within Groups & 67.563 & 99 & .682 & & \\
\hline & Total & 86.835 & 102 & & & \\
\hline \multirow[t]{3}{*}{ Incentives system } & Between Groups & 12.130 & 3 & 4.043 & 4.392 & .006 \\
\hline & Within Groups & 91.132 & 99 & .921 & & \\
\hline & Total & 103.262 & 102 & & & \\
\hline
\end{tabular}

\section{Conclusions and Policy Implications}

As the business development of the business grows, there is a higher level of decentralization and decentralization of the business units. The present result shows that as the size of the business grows, the application of accounting aspects of responsibility accounting becomes clearer. Responsibility accounting provides information that helps executives accomplish their tasks assigned to achieve common goals of the business. Vietnamese cement enterprises should pay close attention to management accounting in general and responsibility accounting in particular. In addition to businesses that are interested in responsibility accounting, there are also companies that do not pay sufficient attention to the tools of responsibility accounting in the enterprise. The results of the study have shown that the higher the level of managers' education, the higher the tendency to apply responsibility accounting in enterprises, improving the competitiveness of enterprises. Therefore, raising the knowledge and level of manager education in the cement production enterprises is very necessary. Therefore, Vietnamese cement enterprises need to work closely with universities and training institutions in the training of students. Vietnamese Cement enterprises should also be involved in teaching and learning activities in the universities to contribute ideas to the development of plans, programs for human resources training closely with the actual work of the business.

\section{References}

Atkinson, A.A., Banker, R.D., Kaplan, R.S., \& Young, S.M. (2001). Management Accounting. $3^{\text {rd }}$ ed.: Prentice Hall.

Al-Bawab, A. A. (2012). Impact of decentralization and responsibility accounting in performance evaluation for the decentralized entities at the Yemenian Banks (An Empirical study). Interdisciplinary Journal of Contemporary Research In Business, 3, 611-626.

Al-Shomaly, I. (2013). Performance evaluation and responsibility accounting. Journal of Management Research, 5(1), $291-301$. Belkaoui, A. (1981). The relationship between self-disclosure style and attitudes to responsibility accounting. Accounting, Organizations and Society, 6(4), 281.

Bloomfield, B. P., Coombs, R., Cooper, D. J., \& Rea, D. (1992). Machines and manoeuvres: Responsibility accounting and the construction of hospital information systems. Accounting, Management and Information Technologies, $2(4), 197-219$.

Dowd, J. E. (2001). Effect of product mix and technology on responsibility accounting, account proliferation and product unbundling in the Texas utility industry. Managerial Auditing Journal, 16(2), 76-87.

E., O. T. (2012). The Relevance of standard costing in Nigerian Organaization - A survey of selected firm in Ughelli, Delta states. Journal of Management and corporate Governance, 4(1), 14-22. 
Fowzia, R. (2011). Use of responsibility accounting and measure the satisfaction levels of service organizations in Bangladesh. International Review of Business Research Papers, 7(5), 53-67.

Garrison, R. H., \& Noreen, E. W. (2008). Managerial Accounting. New York: Mac Graw-Hill.

Gharayba, F., \& Debi, M. M. 'Moon, \& Nasar, A.(2011). The extent of applying the elements of responsibility accounting in the industrial shareholding companies and its effect on the company's profitability and operational efficiency. Administrative Sciences, 38(1), 219-234.

Hanini, A. (2013). The extent of implementing responsibility accounting features in the Jordanian banks. European Journal of Business and Management, 5(1), 217-229.

Hansen, D. R., \& Mowen, M. M. (2005). Management Accounting: Thomson South-Western.

Hermanson, R., Edwards, J. B., \& Salmonson, R. F. (1987). Accounting Principles: Taxes Business Publication Inc.

Higgins, J. A. (1952). Responsibility accounting (Vol. 12). Chicago, IL: The Arthur Andersen chronicle.

Horngren, C. T., Foster, G., \& Datar, S. (2000). Cost accounting: managerial Emphasis: Prentice Hall of India Private Limited, newdelhi.

Kellogg, M. N. (1962). Fundamentals of Responsibility Accounting. National Association of Accountants. NAA Bulletin (pre1986), 43(8), 5.

Kinney, M. F., \& Raiborn, C. A. (2011). Cost accounting. South-Western, Mason, OH.

Meda, I. (2003). System of responsibility accounting in the Jordanian shareholding companies: Reality and hope. Journal of university of Damascus, 19(2), 317-363.

Okoye, E. I., R., E. N., \& Ngozi, I. (2009). Improvement of Managerial Performance in Manufacturing Organizations - An Application of Responsibility Accounting. Journal of the Management Sciences, 9(1), 1-17.

Rajbi, M. T. (2004). The Administrative Accounting (Vol. Dar Wael). Amman, Jordan.

Reddy, B. V. v. R. (2008). Responsibility -Accounting - Conceptual Framework. Retrieved 15/9/, 2013

Rowe, C., Birnberg, J. G., \& Shields, M. D. (2008). Effects of organizational process change on responsibility accounting and managers' revelations of private knowledge. Accounting, Organizations and Society, 33(2/3), 164-198.

Zahirul, H., \& Wendy, J. (2000). Linking balanced scorecard measures to size and market factors: Impact on organizational performance. Journal of Management Accounting Research, 12, 1-17.

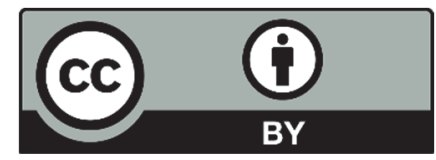

(C) 2020 by the authors; licensee Growing Science, Canada. This is an open access article distributed under the terms and conditions of the Creative Commons Attribution (CC-BY) license (http://creativecommons.org/licenses/by/4.0/). 